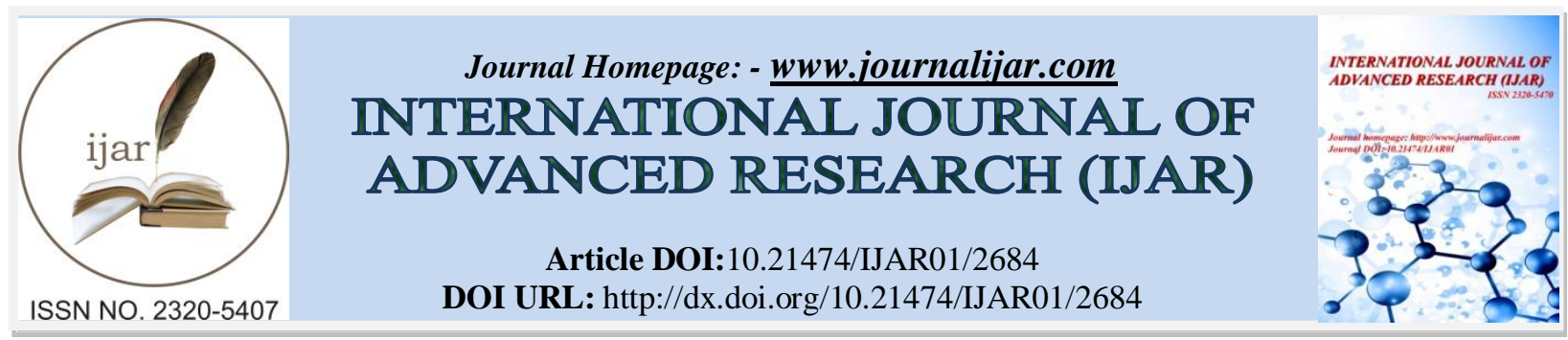

RESEARCH ARTICLE

\title{
A STUDY OF CHANGES IN SERUM CONCENTRATION OF SODIUM, POTASSIUM, CHLORIDE AND MAGNESIUM IN PRE AND POST CISPLATIN AND 5-FLOUROURACIL CHEMOTHERAPY IN HEAD AND NECK CANCER PATIENTS
}

\author{
Uma Das ${ }^{1}$, *Bharati Devi ${ }^{2}$, Kailash Bhattacharyya ${ }^{1 a}$, Keshab Bora ${ }^{3}$ and Pratim Gupta ${ }^{4}$. \\ 1. Formerly Consultant Biochemist, Bangalore Baptist Hospital (first author). \\ 2. Asstt. Professor, Department of Biochemistry, Assam Medical College, Dibrugarh, Assam(second author). \\ 1a.Professor and Head, Deptt. Of Biochemistry, Gauhati Medical College, Guwahati(first author) \\ 3. Demonstrator, Deptt. Of Biochemistry, Assam Medical College, Dibrugarh, Assam. \\ 4. Demonstrator, Deptt. Of Biochemistry, Assam Medical College, Dibrugarh.
}

\section{Manuscript Info}

Manuscript History

Received: 31 October 2016

Final Accepted: 01 December 2016

Published: December 2016

Key words:-

electrolytes, chemotherapy, Assam

\section{Abstract}

A clinical cross-over study was carried out in a tertiary care hospital in Assam to determine and compare the concentration of serum sodium, potassium, chloride and magnesium in head and neck cancer patients before and after cisplatin and 5-flouro uracil chemotherapy and to find out the impact of cisplatin and 5-flouro uracil in serum sodium, potassium, chloride and magnesium concentration in head and neck cancer patients. The present study was conducted in the department of Biochemistry, in collaboration with the department of Otorhinolaryngology, Assam Medical College and Hospital. Fifty (50) patients having histologically proved squamous cell carcinoma of head and neck below 70 years of age attending the department of Otorhinolaryngology were taken into account. Values of serum sodium, potassium, chloride and magnesium were compared before and after $1^{\text {st }}, 2^{\text {nd }}$ and $3^{\text {rd }}$ cycle of cisplatin and 5-fluorouracil chemotherapy. Mean serum sodium, potassium, chloride and magnesium levels were decreased after all the cycles. Paired t test was performed for statistical analysis. $\mathrm{P}$ value $(<0.0001)$ was found to be highly significant. Mean serum creatinine levels were increased after the chemotherapy which is also significant. Our study revealed that hyponatremia, hypochloremia, hypokalemia and hypomagnesemia are the common electrolyte disturbances with cisplatin and 5fluorouracil chemotherapy in head and neck cancer patients. So, close monitoring of renal function and estimation of electrolytes after chemotherapy is recommended.

Copy Right, IJAR, 2016,. All rights reserved.

\section{Introduction:-}

Cancer is a class of disease characterized by uncontrolled cell division and these cells have the ability to invade other tissues by migrating to distant sites by metastasis. Epithelial carcinoma of head and neck arises from the mucosal surfaces and typically are of squamous cell origin. The category includes tumours of the paranasal sinuses, oral cavity, nasopharynx, oropharynx and larynx. ${ }^{1}$ 
Alcohol and tobacco use are the most common risk factors for head and neck cancers. Smokeless tobacco is an etiologic agent for oral cancers. ${ }^{2}$ Other potential carcinogens include marijuana and other occupational exposures such as nickel refining, textile fibres and woodworking. Dietary factors like low consumption of fruits and vegetables may also contribute to head and neck cancer. Some head and cancer may have viral aetiology. The DNA of human papilloma virus has been detected in the tissue of oral cancer in the absence of tobacco and alcohol use. ${ }^{3}$

Patients with head and neck cancer receive chemotherapy usually with cisplatin and 5-flouro uracil. Most patients who receive three cycles of cisplatin and 5-flouro uracil show tumour reduction and the response is clinically complete in up to half. ${ }^{4}$

Cisplatin based chemotherapy is commonly associated with severe electrolyte abnormalities including hyponatremia, hypokalemia, hypomagnesemia, hypocalcimia, Fanconi like syndrome and acute renal failure. ${ }^{5}$ Cisplatin is a tubular nephrotoxin and causes dose dependent nephrotoxicity by particularly affecting the S3 segment of the proximal tubule and to a lesser extent the loop of Henle and the distal collecting system. ${ }^{6}$ This is clinically manifested by reduced GFR causing a rise in serum creatinine and salt wasting due to impaired absorption of sodium in the proximal tubule and the loop of Henle leading to urinary concentration defect. Cisplatin may cause decrease in the number of aquaporin channels in the cortical and medullary collecting duct, thereby further contributing to impaired urinary concentration and polyuria. ${ }^{7,8}$ This may in fact limit the degree of hyponatremia (secondary to decreased water reabsorption) that develops with salt wasting from proximal tubule dysfunction. ${ }^{9}$ Cisplatin is a common cause of hypomagnesemia and hypokalemia due to renal magnesium and potassium losses. ${ }^{10}$ Magnesium plays an important role in the maintenance of intracellular potassium. Unrecognized and untreated magnesium depletion may lead to a refractory potassium depletion.

\section{Aims and objective:-}

1. To determine and compare the concentration of serum sodium, potassium, chloride and magnesium in head and neck cancer patients before and after cisplatin and 5-flouro uracil chemotherapy.

2. To find out the impact of cisplatin and 5-flouro uracil in serum sodium, potassium, chloride and magnesium concentration in head and neck cancer patients.

\section{Materials and Methods:-}

The present study was conducted in the department of Biochemistry, in collaboration with the department of Otorhinolaryngology, Assam Medical College and Hospital. Fifty (50) patients of head and neck cancer attending the department of Otorhinolaryngology were taken into account. This study was designed as a clinical cross-over study.

\section{Selection of cases:-}

\section{Inclusion criteria:-}

- Age of the patient being less than 70 years.

- Histologically proved squamous cell carcinoma.

- Measurable disease for objective evaluation.

- Informed signed consent by the patient.

- Laboratory values: $\mathrm{Hb}>10 \mathrm{gm} \%$, Absolute polymorphonuclear cell count $>1800$, platelet count $>100,000 \mathrm{~mm}^{3}$, serum creatinine $<1.2 \mathrm{mg} / \mathrm{dl}$, serum bilirubin $<1 \mathrm{mg} / \mathrm{dl}$.

\section{Exclusion criteria:-}

- Presence of distant metastases.

- Second primary tumour.

- Prior anti-cancer treatment.

- No active ischaemic heart disease.

- No myocardial infarction within the past 6 months.

- Presence of any renal disease.

- No active infection. 
The following investigations were done in each of the cases:-

- Estimation of serum sodium, potassium and chloride by ion selective technology.

- Estimation of serum magnesium by Calmagite method.(Manufacturer: Coral Clinical Systems, Gitanjali, Dr.Antonio Do Rego Bagh, Bambolim Complex, Goa-403202)

- Estimation of serum Creatinine by alkaline picrate method(Manufacturer: Coral Clinical Systems, Gitanjali, Dr.Antonio Do Rego Bagh, Bambolim Complex, Goa-403202)

\section{Results:-}

Age and sex distribution of the subjects: It was found that the maximum number of cases 27 (54\%) were in the age group of $60-70$ years, followed by $14(28 \%)$ in the age group of $50-59$ years and $9(18 \%)$ below 50 years. Out of total 50 cases, $38(76 \%)$ were male and $12(24 \%)$ were female.

In the present study of 50 cases, all were histopathologically proved to be squamous cell carcinoma and distributed at the different sites as shown in table 1 .

Hypopharynx is the commonest site with 18 (36\%) patients and maxillary sinus the least with 2 (4\%) patients.

Values of serum sodium, potassium, chloride and magnesium were compared before and after $1^{\text {st }}, 2^{\text {nd }}$ and $3^{\text {rd }}$ cycle cisplatin and 5-fluorouracil chemotherapy. Mean serum sodium, potassium, chloride and magnesium levels were decreased after all the cycles. Paired $t$ test was performed for statistical analysis. P value was found to be highly significant. Mean serum creatinine levels were increased after the chemotherapy which is also significant.

Table 1:-

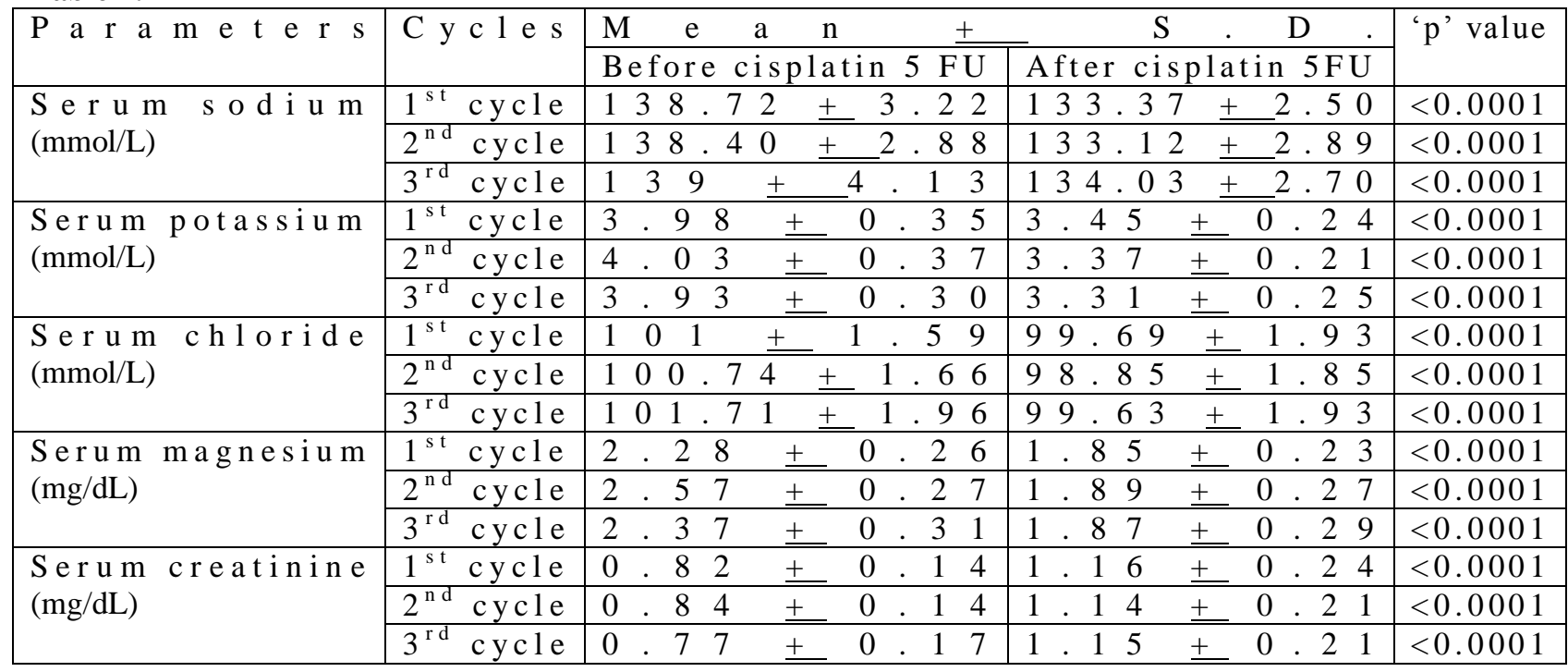




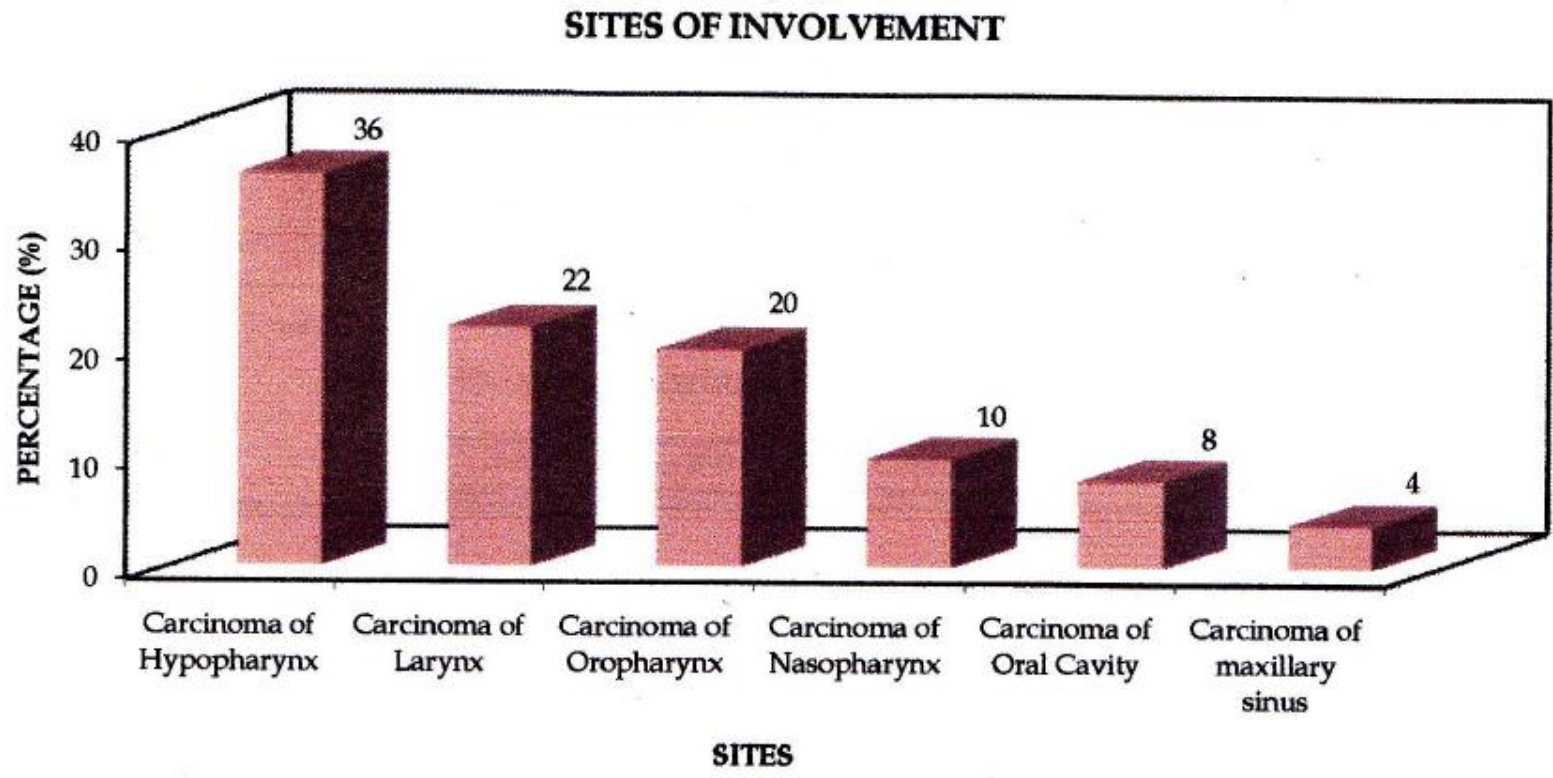

Figure1:-

COMPARISON OF SERUM SODIUM BEFORE AND AFTER $1^{\mathrm{ST}}, 2^{\mathrm{ND}}$ AND $3^{\mathrm{RD}}$ CYCLE OF CISPLATIN AND 5 FLUOROURACIL (5FU) CHEMOTHERAPY

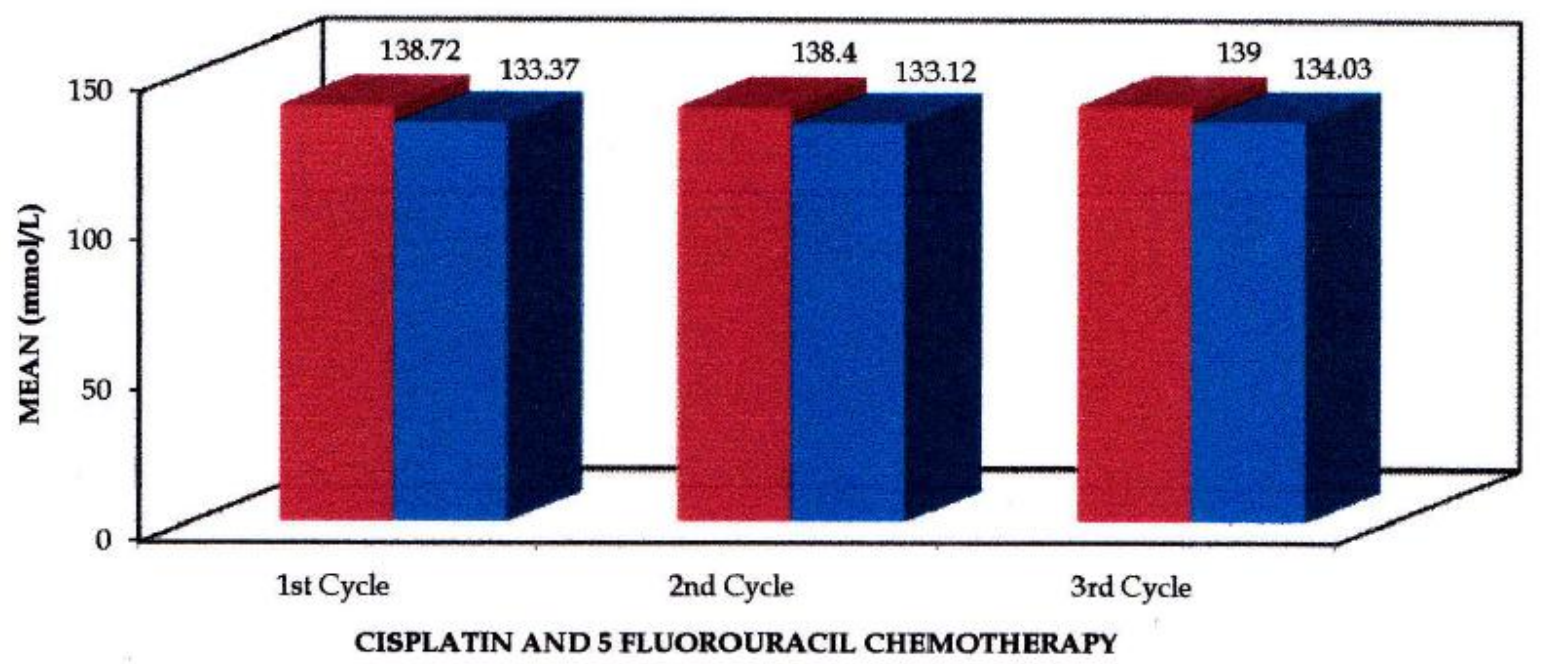

Before Cisplatin 5FU After Cisplatin 5FU

Figure 2:- 
COMPARISON OF POTASSIUM BEFORE AND AFTER $1^{\mathrm{ST}}, 2^{\text {ND }}$ AND $3^{\text {RD }}$ CYCLE OF CISPLATIN AND 5 FLUOROURACIL (5FU) CHEMOTHERAPY

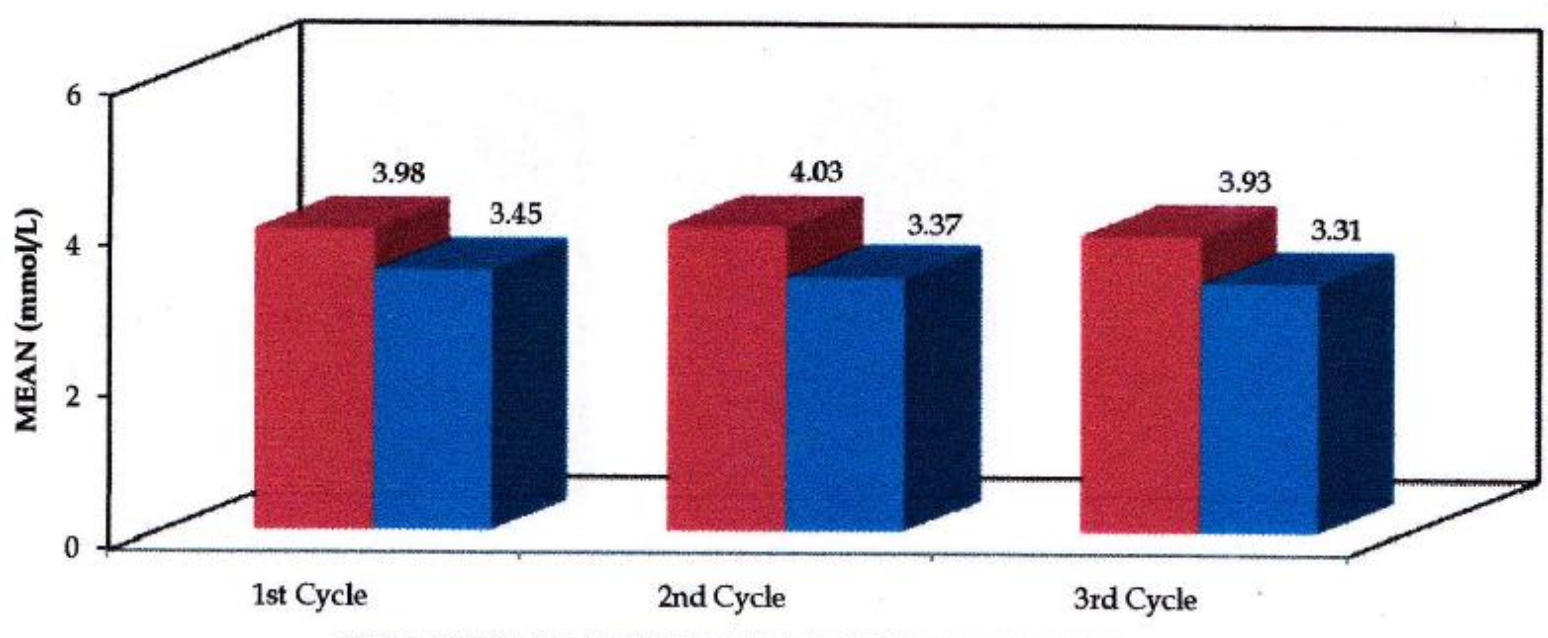

CISPLATIN AND 5 FLUOROURACIL CHEMOTHERAPY

= Before Cisplatin 5FU After Cisplatin 5FU

Figure 3:-

COMPARISON OF CHLORIDE BEFORE AND AFTER $1^{\mathrm{ST}}, 2^{\text {ND }}$ AND $3^{\text {RD }}$

OF CISPLATIN AND 5 FLUOROURACIL (5FU) CHEMOTHERAPY

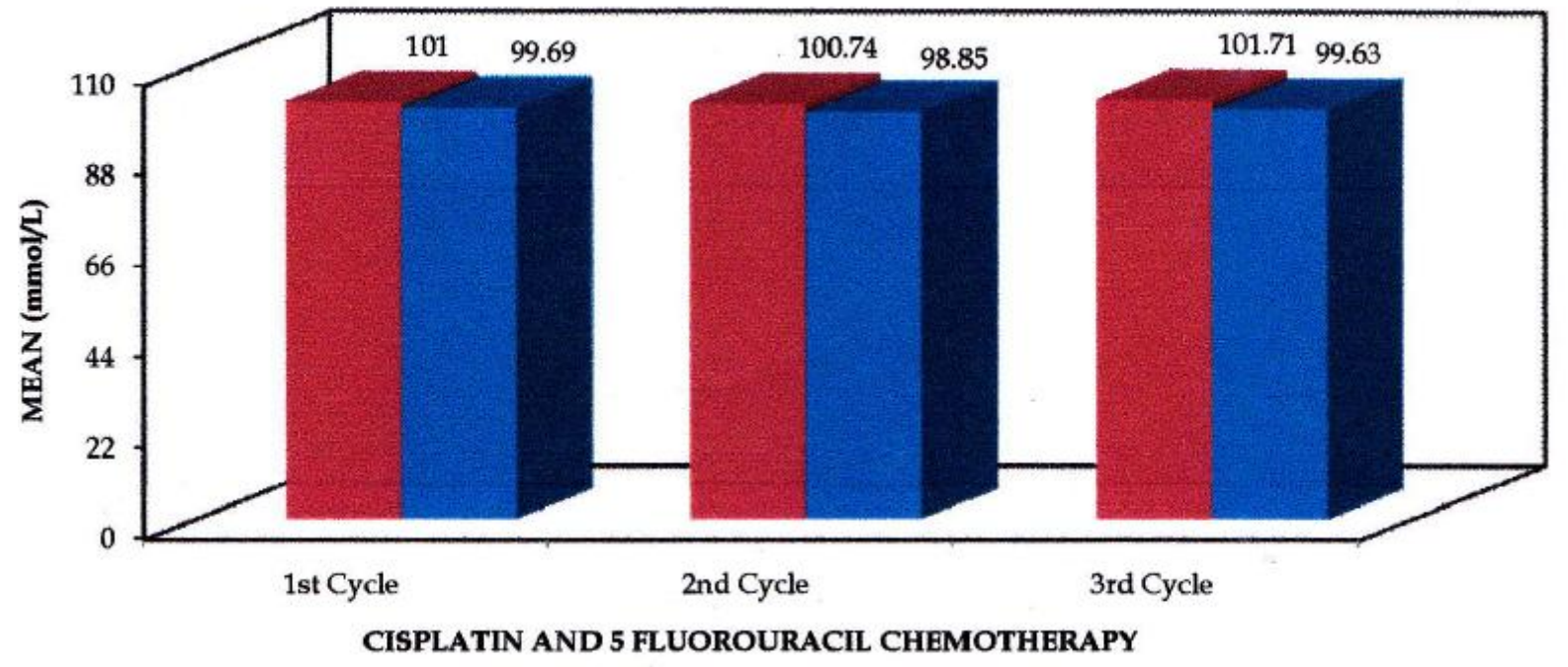

Before Cisplatin 5FU After Cisplatin 5FU

Figure 4:- 

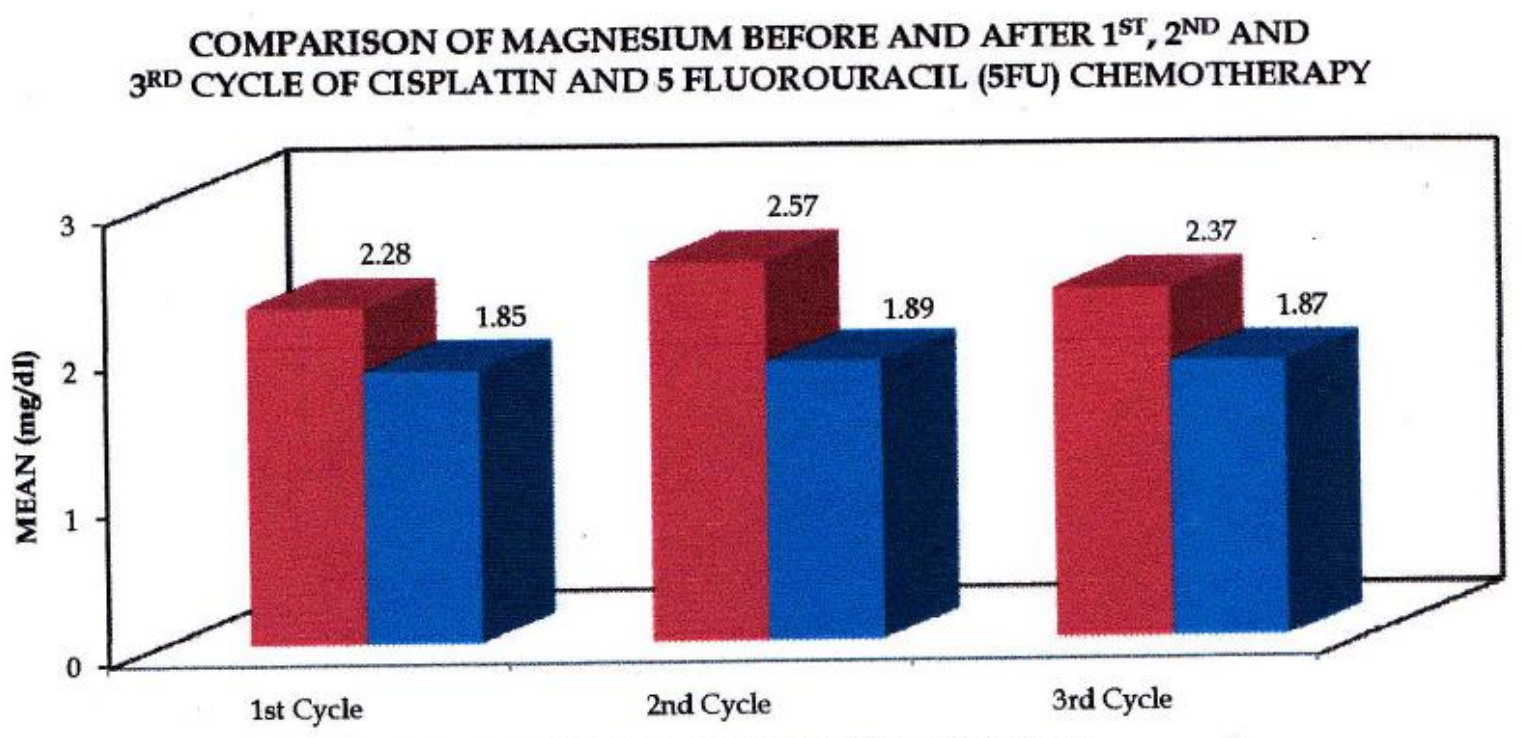

CISPLATIN AND 5 FLUOROURACIL CHEMOTHERAPY

sefore Cisplatin 5FU $\quad$ After Cisplatin 5FU

Figure 5:-

COMPARISON OF SERUM CREATININE BEFORE AND AFTER $1^{\mathrm{ST}}, 2^{\mathrm{ND}}$ AND $3^{\text {RD }}$ CYCLE OF CISPLATIN AND 5 FLUOROURACIL (5FU) CHEMOTHERAPY

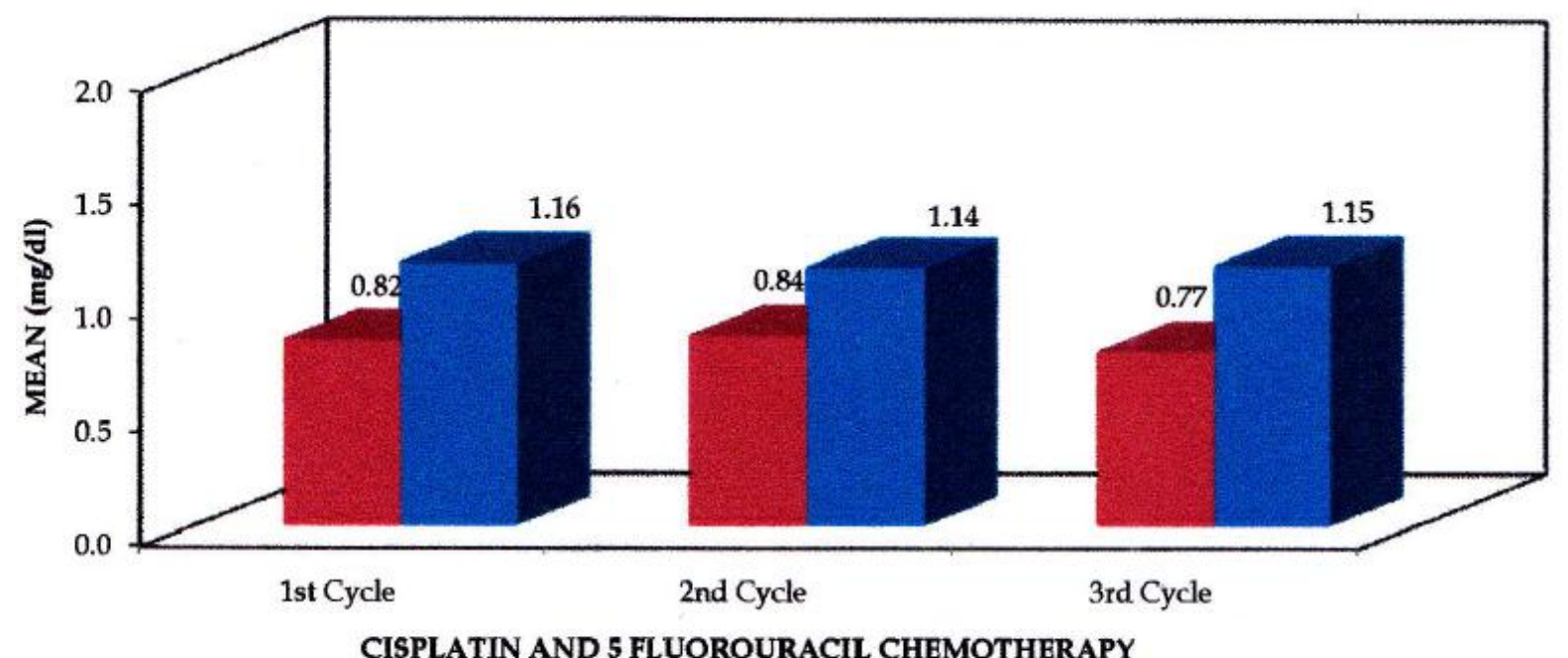

$\approx$ Before Cisplatin 5FU After Cisplatin 5FU

Discussion:-

Figure 6:-

Cancer is a disease of old age, but several authorities have reported in the young age too. ${ }^{11,12,13}$. Baruah et al (1964) has found the highest incidence in the age group of $41-50$ years. ${ }^{14}$

Gandagule and Agarwal et al $(1959)^{15}$ has found that the average to be 52.8 years. In this series, the peak incidence was found in the age group of $60-70$ years. 
There is a general agreement in the literature of a higher male preponderance of squamous cell carcinoma of head and neck region. ${ }^{16,17,18}$. Paymaster et al $(1971)^{19}$ reports male to female ratio as 9:1 in his series. In this series the male to female ratio was $3.17: 1$.

Paymaster et al (1971) ${ }^{19}$ has found highest incidence in hypopharyngeal region. Our study showed 36\% hypophryngeal cancer, $22 \%$ in larynx, $20 \%$ in oropharynx, $10 \%$ in nasopharynx, $8 \%$ in oral cavity and $2 \%$ in maxillary sinus.

Renal toxicity is a common and dose-limiting feature of cisplatin. It may be acute or late onset electrolyte imbalance. $^{20,21}$ Acute fluid and electrolyte imbalances seen during first 24 hours period after chemotherapy, late symptoms occur more than 24 hours after chemotherapy and can last for up to $3-7$ days. ${ }^{22}$ In our study, serum sodium, potassium, chloride and magnesium were evaluated during first 24 hours of cisplatin chemotherapy.

Serum sodium and chloride levels showed obvious and progressive decline in our patients. Hyponatremia is not an uncommon clinical syndrome. In previous studies, authors have found that both renal salt wasting syndrome and syndrome of inappropriate antidiuretic hormone secretion have been reported as the underlying mechanism for cisplatin chemotherapy induced hyponatremia. ${ }^{23}$ In present study, there was a significant hyponatremia seen in $58.66 \%$ patients and mild hypochloremia seen in $22 \%$. Asim Jamal Shaikh et al has found hyponatremia in $67.9 \%{ }^{24}$

Present study showed a significant decrease in serum potassium (68\%) after cisplatin and 5 fluorouracil treatment. Hypokalemia is due to increased renal reabsorption capacity observed in response to decreased intestinal absorption of potassium. Potassium metabolism subjected to predictable changes in intestinal absorption and renal excretion with each cisplatin based treatment. Asim Jaml Shaikh et al reported hypokalemia in $48 \%$ patients. ${ }^{24}$ In some reports, the hypokalemia in cisplatin based chemotherapy was associated with paralysis. ${ }^{25}$ Henceforth, for the prevention of hypokalemic paralysis, the patients are advised to undergo regular serum electrolyte measurement for early detection of cation deficiency and appropriate replacement of cations.

Our study showed a significant decrease in serum magnesium upon cisplatin and 5-fluorouracil chemotherapy. We observed hypomagnesemia in up to $47.66 \%$ receiving chemotherapy. Asim Jaml Shaikh et al found hypomagnesemia in $54.3 \% .{ }^{24}$ Our study results were in accordance with the study of Gomez Campdera et al ${ }^{26}$.

Magnesium plays an important role in the maintenance of intracellular $\mathrm{K}^{+}$level. Concomitant $\mathrm{Mg}^{++}$deficiency in $\mathrm{K}^{+}$ - depleted patients ranged from $38 \%$ to $42 \%{ }^{27}$. It is recommended that serum $\mathrm{Mg}^{++}$is routinely assessed, and that until serum $\mathrm{Mg}^{++}$is measured consideration should be given to treating hypokalemic patients with both $\mathrm{Mg}^{++}$and $\mathrm{K}^{+28}$

In present study, we also analyzed serum creatinine to assess renal function and excretion of this component is the function of lean body mass in normal person. In our study, creatinine was increased significantly (46\%) after cisplatin treatment which may be due to acute nephrotoxicity.

\section{Conclusion:-}

Our study revealed that hyponatremia, hypochloremia, hypokalemia and hypomagnesemia are the common electrolyte disturbances with cisplatin and 5fluorouracil chemotherapy in head and neck cancer patients. These adverse reactions may range from mild to potentially fatal. This chemotherapy regimen may induce magnesium depletion and magnesium deficiency itself may enhance nephrotoxicity. Hypokalemia may be symptomatic and require prolonged admission especially if associated with hypomagnesemia. Cisplatin and 5fluorouracil chemotherapy may cause acute tubular necrosis, restricting the tubule's ability to reabsorb water, sodium, magnesium, potassium and other electrolytes resulting in electrolyte abnormality that may become chronic. So, close monitoring of renal function and estimation of electrolytes after chemotherapy is recommended. 


\section{References:-}

1. Fauci AS, Braunwald E, Kasper DL, Longo DL, Hauser SL, Jameson JL et al, editors. Harrison's principles of internal medicine. $17^{\text {th }}$ ed. New York: McGraw-Hill; 2008. p. 548.

2. Bhonsle RB, Murti PR, Gupta PC. Tobacco habits in India. In: Gupta PC, Hamner JE, Murti PR, editors. Control of tobacco-related cancers and other diseases. Proceedings of an international symposium; 1990 Jan 15-19. Bombay: Oxford University Press; 1992. p. 25-46.

3. Adelstein DJ, Ridge JA, Gilison ML, Chaturvedi AK, D’Souza G, Gravitt PE et al. Head and neck squamous cell cancer and the human papilloma virus: summary of a national cancer institute state of the science meeting; 2008 Nov 9 - 10; Washington, D.C: Head Neck 2009 Nov;31(11):1393-422.

4. Pruefer FG, Lizarraga F, Maldonado V, Melendez-Zajgla J. Participation of Omi Htra2 serine protease activity in the apoptosis induced by cisplatin on SW480 colon cancer cells. J Chemother 2008 Jun;20(3):348-54.

5. Hartmann JT, Lipp HP. Toxicity of platinum compounds. Expert Opin Pharmac other 2003 Jun;4(6):889-901.

6. Arany I, Safirstein RL. cisplatin nephrotoxicity. Semin Nephrol 2003 Sep;23(5):460-4.

7. Sastry J, Kellie SJ. Severe neurotoxicity, ototoxicity and nephrotoxicity following high dose cisplatin and amifostine. Pediatr Hematol Oncol 2005 Jul-Aug;22(5):441-5.

8. Boulikas T. Poly (ADP-ribose) synthesis in blocked and damaged cells and its relation to carcinogens. Anticancer Res 1992; $12: 885-898$.

9. Weshi A, Thieblemont C, Cottin V, Berbet N, Catimel G. Cisplatin induced hyponatremia and renal sodium wasting. Acta oncol 1995;34:264-5.

10. Schilsky RL, Anderson T. Hypomagnesemia and renal magnesium wasting in patients receiving cisplatin. Ann Intern Med 1979 Jun;90(6):929-31.

11. Buck RP, Lindner E. Recommendations for nomenclature of Ion-selective electrodes. Pure Appl Chem 1994;66:252736.

12. Abernethy MH, Fowler RT. Micellar improvement of the calmagite compleximetric measurement of magnesium in plasma. Clin chem 1982 Mar;28(3):520-2.

13. Leidtke RJ, Kroon G. Automated camagite compleximetric measurement of magnesium in serum, with sequential addition of EDTA to eliminate endogenous interference. Clin chem 1984 Nov;30(11):1801-4.

14. Bones RW, Tausky HH. Colorimetric determination of creatinine by the Jaffe reaction. J Biol Chem 1945;158:581591.

15. Toro G, Ackermann PG. Practical Clinical Chemistry. Boston: Little Brown and Co; 1975. p. 154

16. Hart AE, Karakla DW, pitman KT, Adams JF. Oral and oropharyngeal squamous cell carcinoma in young adults: a report on 13 cases and review of the literature. Otolayngol Head Neck Surg 1999 Jun;120(6):828-33.

17. Mallet Y, Avalos N, Le ridant A, Gangloff P, Moriniere S, Rame J et al. Head and neck cancer in young people: a series of 52 SCCs of the oral tongue in patients aged 35 years or less. Acta Otolaryngol 2009;129:1503-8.

18. Lacy PD, Piccirillo JF, Merritt MG, Zequeira MR. Head and neck squamous cell carcinoma: better to be young. Otolaryngol Head Neck Surg 2000 Feb;122(2):253-8.

19. Baruah BD. Cancer in Assam. Observations based on a study of 2493 biopsy specimen of malignant tumours. Cancer 1964 Apr;17(4):413-431.

20. Gandagule VN, Agarwal S. Oral and pharyngeal cancer in MadhyaPradesh. J Indian Med Assoc 1969;53:582-85.

21. Mackenzie J, Ah-See K, Thakker N, Sloan P, Maran AG, Birch J et al. Increasing incidence of oral cancer amongst young persons: what is the etiology? Oral Oncol $2000 \mathrm{Jul} ; 36(4): 387-9$.

22. Iype EM, Pandey M, Matthew A, Thomas G, Sebastian P, Nair MK. Oral cancer among patients under the age of 35 years. J Postgrad Med 2001;47:171-176.

23. Cusumano RJ, Persky MS. Squamous cell carcinoma of the oral cavity and oropharynx in young adults. Head Neck Surg 1988 Mar-Apr;10(4):229-34.

24. Shaikh AJ, Masood N, Adil SN, Bawany SA, Khan AA, Kumar S. Electrolyte imbalances in patients admitted with chemotherapy-induced febrile neutropenia: patterns and impact on outcomes, a single-centre study from Pakistan. J Clin Oncol 2009;27

25. Paymaster JC, Gangadharan P. Mortality from cancer in greater Bombay. J Indian Med Assoc 1971 Jul 16;57(2):639.

26. Wickham R. Nausea and vomiting. In: Yarbo $\mathrm{CH}$, Frogge $\mathrm{MH}$, Goodman M, editors. Cancer symptom management. $2^{\text {nd }}$ ed. Sudbury: Jones and Bartlett Publishers; 1999. p. 228-263.

27. Coates A, Abraham S, Kaye SB, Sowerbutts T, Frewin C, Fox RM et al. On the receiving end- patient perception of the side effects of cancer chemotherapy. Eur J Cancer Clin Oncol 1983 Feb;19(2):203-8.

28. National cancer institute. Common terminology criteria for adverse events (CTCAE)-version 4.0. Bethesda Md: US Department of Health and Human Services, National Institute of Health; 2010. 